\title{
EFEKTIVITAS KONSELING KELOMPOK TEKNIK RELAKSASI UNTUK MENGATASI KESULITAN BELAJAR PESERTA DIDIK SMP PGRI 1 PALEMBANG
}

\author{
Arizona \\ Prodi Bimbingan dan Konseling, Universitas PGRI Palembang, Indonesia \\ arizona.karno@gmail.com
}

\begin{abstract}
Abstrak
Tujuan penelitian ini adalah: (1) mengetahui keefektifan konseling kelompok dan mengatasi kesulitan belajar siswa di SMP PGRI 1 Palembang, (2) mengetahui keefektifan model konseling kelompok dengan teknik relaksasi berbasis musik intrumental untuk mengatasi kesulitan belajar siswa SMP PGRI 1 Palembang. Penelitian ini adalah penelitian kuantitatif Metode Quasi experiment design dengan Nonequivalent Control Group Design dilaksanakan untuk memperoleh gambaran tentang efektivitas konseling kelompok melalui teknik relaksasi berbasis musik instrumental untuk mengatasi kesulitan belajar siswa SMP PGRI 1 Palembang dengan langkah-langkah: (1) persiapan kelompok kontrol dan kelompok eksperimen, (2) memberikan pretest pada kelompok kontrol dan eksperimen (3) memberikan tretment atau perlakuan ke kelompok eksperimen (4) memberikan post test pada kelompok eksperimen, (5) hasil akhir keefektifan konseling kelompok dengan teknik relaksasi berbasis musik intrumental untuk mengatasi kesulitan belajar siswa. Penelitian ini menghasilkan efektivitas konseling kelompok dengan teknik relaksasi berbasis musik instrumental untuk mengatasi kesulitan belajar siswa. Penelitian ini melibatkan 14 siswa sebagai sampel 7 sebagai kelompok eksperimen dan 7 sebagai kelompok kontrol. Berdasarkan hasil uji lapangan, tingkat kesulitan belajar siswa mengalami peningkatan setelah mengikuti kegiatan konseling kelompok dengan teknik relaksasi diri. Ditunjukkan dengan perubahan tingkat kesulitan belajar siswa sebelum diberikan perlakuan (evaluasi awal) dan sesudah (evaluasi akhir) sebesar 147 poin atau $99 \%$. Hasil uji statistik perhitungan uji wilcoxon juga menunjukkan $0,005<0,05$ sehingga dapat disimpulkan bahwa layanan konseling kelompok dengan teknik relaksasi berbasis musik intrumental efektif untuk mengatasi kesulitan belajar siswa.
\end{abstract}

Kata kunci: kesulitan belajar, konseling kelompok, musik instrumental, relaksasi.

\section{Abstract}

The objectives of this research are: (1) to know the effectiveness of group counseling and to overcome student's learning difficulties in SMP PGRI 1 Palembang, (2) to know effectiveness of group counseling model with intrumental music based relaxation technique to overcome student learning difficulties SMP PGRI 1 Palembang. This reasearch use Quantitative approach Quasi-experimental design method with Non equivalent Control Group Design was conducted to obtain an overview of the effectiveness of group counseling through instrumental music-based relaxation techniques to overcome the learning difficulties of SMP PGRI 1 Palembang students by the following steps: (1) preparation of control groups and experimental groups, 2) provide a pre-test in the control and experimental group (3) provide treatment or treatment to the experimental group (4) provide post test in the experimental group, (5) the final outcome of group counseling effectiveness with instrument music-based relaxation techniques to overcome learning difficulties students. This study resulted in the effectiveness of group counseling with intrumental music-based relaxation techniques to overcome student learning difficulties. The study involved 14 students as a sample of 7 as an experimental group and 7 as a control group. Based on the results of field tests, the level of self efficacy of students increased after following group counseling activities with self-relaxation techniques. Shown by changes in student's learning difficulty level before being given treatment (preliminary evaluation) and after (final evaluation) of 147 points or $99 \%$. The result of statistical test of wilcoxon test also shows $0,005<0,05$ so it can be concluded that group counseling service with intrumental music based relaxation technique is effective to overcome student's learning difficulties.

keywords: group counseling, instrumental music, learning difficulties, relaxation. 


\section{PENDAHULUAN}

Sekolah merupakan salah satu tempat untuk penyelenggaraan pendidikan, yang didalamnya berlangsung proses belajar mengajar dan proses konseling, tapi pada kenyataanya pelaksanaan konseling kelompok yang sudah dilakukan masih secara konvensional dan belum menggunakan teknik-teknik khusus dalam membantu siswa untuk mengembangkan dirinya dan menyelesaikan suatu permasalahan siswa. Ditinjau dari perspektif bimbingan dan konseling, jelas sekali bahwa tugas guru bimbingan dan konseling sangat dibutuhkan dalam rangka menyelesaikan masalah siswa yang ada di sekolah. Selain itu juga untuk membimbing, mengarahkan dan memandirikan serta mengembangkan potensi-potensi perserta didik sampai peserta didik yakin akan kemampuan pada dirinya, sehingga dapat menyelasaikan masalah yang peserta didik hadapi. Jika seorang peserta didik memiliki kesulitan belajar yang rendah maka ini akan menjadi masalah dan mempengaruhi prestasi dan nilai akademik peserta didik.

Ketika kesulitan belajar tinggi individu merasa dapat melakukan respon tertentu untuk memperoleh reinforcemant. Sebaliknya jika kesulitan belajar rendah maka individu merasa cemas, tidak mampu melakukan respon tersebut (Syamsu, dalam Nurihsan 2008:135).

Proses pembelajaran keberhasilan pembelajaran dapat timbul dari dua aspek yaitu dari luar diri dan dari dalam diri individu, dari luar diri individu itu berasal dari guru dan sistem pembelajaran sedangkan dari dalam diri itu adalah kepribadian salah satunya adalah kesulitan belajar. Zulkosky (2009: 95) menyatakan kesulitan belajar terkait dengan penilaian seseorang terhadap kemampuan dirinya untuk melakukan aktivitas tertentu untuk mencapai hasil tertentu. Hal ini menjadikan individu menjadi berpikir dan bertingkah laku (keputusankeputusan yang akan di ambil, usahanya, dan keteguhannya pada saat menghadapi masalah).

Bandura (1997:5) menyatakan dalam kondisi yang sulit, orang dengan kesulitan belajar rendah cenderung mudah menyerah, sementara individu dengan kesulitan belajar yang tinggi akan berusaha lebih keras untuk mengatasi tantangan yang dihadapinya. Jadi kesulitan belajar itu ialah keyakinan seseorang bahwa dirinya mampu mengatur dan melakukan tindakan untuk menyelesaikan suatu tugas.
Mukhid.A,(2009:108) menyatakan kesulitan belajar adalah keyakinan penilaian diri berkenaan dengan kompetensi seseorang untuk sukses dalam tugas-tugasnya. Hal ini bahwa konsep tentang kesulitan belajar berkaitan dengan sejauh mana individu mampu menilai kemampuan, potensi, serta kecenderungan yang ada pada dirinya untuk dipadukan menjadi tindakan tertentu dalam mengatasi situasi yang mungkin dihadapi dimasa yang akan datang.

Konsep negatif yang melatarbelakangi masalah akademik memang sudah sering menjadi masalah sehingga menjadi kecemasan tersendiri sehingga menganggap dirinya tidak mampu dalam menyelesaikan tugas-tugas yang diberikan pada individu itu. Permasalahan individu dengan kesulitan belajar rendah yang memiliki pikiran yang irasional dan pandangan negatif yang dapat menimbulkan perilaku maladaptif dikarenakan adanya penyimpangan fungsi kognitif. Individu itu merasa dirinya tidak mampu atau tidak yakin dengan kemampuan dirinya dalam menyelesaikan tugas yang diberikan. Penyimpangan fungsi kognitif ini dengan merasa tidak yakin dengan kemampuan dirinya akan berpengaruh besar dengan kesuksesan individu hal ini bisa menyebabkan keputusasaan. Dari latar belakang masalah inilah penulis berasumsi bahwa akar permasalahan dari individu yang memiliki kesulitan belajar itu adalah ketidakyakinan atas kemampuan dirinya dalam menyelesaikan tugasnya, dipengaruhi kondisi fisik-emosi sehingga membentuk pikiran-pikiran irasional yang sebenarnya belum tentu ada bukti kebenarannya.

Penelitian ini akan menggunakan konseling kelompok teknik relaksasi berbasis musik intrumental karna untuk merubah pola pikir teknik relaksasi bisa digunakan dalam mengatasi kesulitan belajar, karna relaksasi selain bisa merubah pola pikir individu teknik ini juga dapat mengurangi kecemasan, pengelolaan stres dan bisa mengatasi konsentrasi, adapun musik yang menjadi basis karena dengan musik inidividu dapat mengurangi rasa cemas dan juga dapat mengatasi kreativitas maka dari itu peneliti mengambil teknik relaksasi berbasis musik intrumental untuk mengatasi kesulitan belajar siswa penlitian ini di tunjang oleh Teori yang menyatakan musik bisa membuat suasana belajar jadi rileks. Dengan demikian, belajar yang diiringi musik menjadi lebih kondusif dan menyenangkan. Musik pengiring membantu mengatasi relaksasi. Kondisi ini dapat mengoptimalkan proses belajar, 
menghilangkan kecemasan dan ketegangan sehingga kosentrasi dalam mempelajari materi baru meningkat (Jack C. Richard dan Teodores dalam I Hastomi dan E Sumaryati : 2012).

Teknik relaksasi berbasis musik instrumental ini tetap dilaksanakan dalam suasana kelompok, karena angota kelompok bisa menyarankan dan menawarkan solusi yang potensial.sebagai salah satu teknik yang dapat diterapkan dalam suasana kelompok maka dari itu penelitian ini di beri judul "Efektivitas Konseling Kelompok Dengan Teknik Relaksasi Berbasis Musik Instrumental Untuk Mengatasi Kesulitan belajar Siswa" Tujuan dari penelitian ini adalah untuk melihat sejauh apa efektivitas konseling kelompok dengan teknik relaksasi berbasis musik instrumental untuk mengatasi kesulitan belajar siswa di SMP PGRI 1 Palembang . Berkaitan dengan rumusan masalah dari penelitian ini maka tujuan dari penelitian ini sebagai berikut: 1) Menganalisis pelaksanaan layanan konseling kelompok SMP PGRI 1 Palembang 2) Menganalisis kesulitan belajar siswa di SMP PGRI 1 Palembang Sumatera Selatan. 3) Mengetahui keefektifan layanan konseling kelompok menggunakan teknik relaksasi berbasis musik instrumental untuk mengatasi kesulitan belajar siswa

\section{METODE}

Metode penelitian yang digunakan dalam penelitian ini adalah Quasi Eksperimen dengan design menggunakan metode Non-equivalent Control Group Desain. Bentuk eksperimen ini digunakan untuk mengatasi kesulitan menentukan kelompok kontrol dalam penelitian, Sugiyono (2010:114-116). Metode Non-equivalent Control Group Design ini merupakan metode yang memberikan pre-test terlebih dahulu tanpa memilih secara random baik kelompok kontrol maupun kelompok eksperimen sehingga hasil perlakuan dapat diketahui lebih akurat.

Populasi dalam penelitian ini adalah siswa SMP PGRI 1Palembang Sumatera Selatan. dengan jumlah sampel sebanyak 14 orang siswa kelas VIII. Pengambilan sampel dalam penelitian ini menggunakan teknik purposive sampling. Data penelitian ini, diperoleh dari skala kesulitan belajar.

\section{HASIL PENELITIAN}

\section{Kondisi Pelaksanaan Layanan Konseling Kelompok di SMP PGRI 1 Palembang}

Gambaran tentang pelaksanaan layanan konseling kelompok, peneliti melaporkan berdasarkan hasil wawancara pada guru Bimbingan dan Konseling dan beberapa guru BK atau konselor lainnya. Wawancara yang dilakukan oleh peneliti berfokus pada data yang berkaitan dengan: (a) perencanaan konseling kelompok, (b) pelaksanaan konseling kelompok, (c) materi atau permasalahan dalam konseling kelompok, (d) waktu dan jadwal konseling kelompok, (e) sasaran yang digunakan dalam kegiatan konseling kelompok, (f) evaluasi dan tindak lanjut, (g) faktor penunjang dan penghambat. $(\mathrm{H})$ evaluasi pelaksanaan konseling kelompok yang berupa penilaian segera (laiseg).

\section{Konseling Kelompok Dengan Teknik Relaksasi Untuk Mengatasi kesulitan belajar Siswa \\ Penelitian ini untuk mengetahui tinggi} rendahnya kesulitan belajar siswa diukur dengan skala kesulitan belajar yang ditinjau dari kesulitan belajar yang terdiri dari 9 indikator yang dijabarkan pada 54 butir dan 37 butir yang teruji validitasnya dengan jumlah siswa 35 . Kategori yang digunakan untuk menentukan kesulitan belajar adalah tinggi, sedang, rendah, kurang. Untuk pelaksanaan intervensi dan subjek penelitian dilaksanakan di SMP PGRI 1 Palembang dengan pertimbangan bahwa dari 7 indikator kesulitan belajar, kebanyakan dialami oleh siswa SMP PGRI 1 Palembang. Untuk itu penelitian ini dilaksanakan di SMP PGRI 1 Palembang.

Kesulitan belajar siswa SMP PGRI 1 Palembang dijelaskan pada Tabel 1. 
Tabel 1. Tingkat Kesulitan Belajar siswa SMP PGRI 1 Palembang

\begin{tabular}{llcc}
\hline \multirow{2}{*}{$\begin{array}{l}\text { KODE } \\
\text { SISWA }\end{array}$} & \multicolumn{3}{c}{ Aspek Kesulitan Belajar } \\
& JUMLAH & $\%$ & Keterangan \\
\hline R-1 & 93 & 63 & S \\
R-2 & 90 & 61 & K \\
R-3 & 95 & 64 & S \\
R-4 & 90 & 61 & K \\
R-5 & 94 & 64 & S \\
R-6 & 88 & 60 & K \\
R-7 & 86 & 58 & K \\
\hline
\end{tabular}

Dari tabel 1 dapat dijelaskan bahwa dari beberapa indikator kesulitan belajar masingmasing indikator memiliki kategori yang berbedabeda. aspek satu berada pada kategori kurang dengan persentase $58-61 \%$, indikator sedangakan aspek ke dua berada pada kategori sedang dengan persentase 63\%. Data ini memperkuat asumsi bahwa kesulitan belajar siswa di SMP PGRI 1 Palembang perlu untuk ditingkatkan. Berdasarkan hasil skala kesulitan belajar siswa sesuai dengan permasalahan yang terjadi di lapangan, bahwa siswa masih belum mengetahui kemampuan akan dirinya sendiri dengan baik, serta bagaimana harus mengatasi kesulitan belajar dengan teknik relasasi.

\section{Hasil Uji Efektivitas Konseling Kelompok Teknik Relaksasi Berbasis Musik Intrumental untuk Mengatasi Kesulitan Belajar Siswa}

Secara kuantitatif menurunnya kesulitan belajar siswa bisa dilihat dari perbandingan nilai evaluasi awal (pre test) dan evaluasi akhir (post test) yang diperoleh masing-masing anggota kelompok pada tabel 2.

Tabel 2. Hasil Data Pretest Dan Posttest

\begin{tabular}{c|cc}
\hline Kode Responden & $\begin{array}{c}\text { Pre } \\
\%\end{array}$ & $\begin{array}{c}\text { Pos } \\
\%\end{array}$ \\
\hline R-1 & 69 & 38 \\
R-2 & 75 & 43 \\
R-3 & 100 & 31 \\
R-4 & 69 & 43 \\
R-5 & 75 & 50 \\
R-6 & 75 & 38 \\
R-7 & 56 & 38 \\
R-8 & 87 & 50 \\
R-9 & 81 & 43 \\
\hline
\end{tabular}

Secara keseluruhan, skor kesulitan belajar siswa mengalami kenaikan 116 poin atau sebesar $7,8 \%$. Peningkatan skor kesulitan belajar siswa tidak lepas dari proses yang dialami oleh siswa berupa dinamika kelompok yang terjadi dari setiap pertemuan dalam pelaksanaan konseling kelompok dengan teknik relaksasi berbasis musik intrumental.

Uji keefektifan model layanan konseling kelompok dengan teknik relaksasi berbasis musik intrumental untuk mengatasi kesulitan belajar siswa dianalisa dengan Uji wilcoxon melalui program SPSS. Syarat uji wilcoxon adalah perbedaan dua kelompok data berdistribusi normal. Peneliti terlebih dahulu harus melakukan dahulu uji normalitas pada perbedaan kedua kelompok tersebut. Peneliti melakukan uji normalitas dengan Shapiro Wilk dan diperoleh nilai signifikan sebesar 0,005 ( $p>0,05$ berarti data adalah tersebut normal. Selanjutnya dilakukan analisis dengan uji wilcoxon. Berikut ini akan diuraikan hasil rangkuman pengujian keefektifan model layanan konseling kelompok dengan teknik relaksasi berbasis musik instrumental untuk mengatasi kesulitan belajar siswa. Hasil uji wilcoxon dijelaskan pada Tabel 2

Tabel 2 uji Wilcoxon

Test Statistics ${ }^{a}$

\begin{tabular}{|c|c|}
\hline & $\begin{array}{c}\text { Post Test- } \\
\text { Pre Test }\end{array}$ \\
\hline 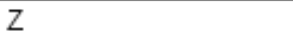 & $-2,805^{b}$ \\
\hline Asymp. Sig. (2-tailed) & ,005 \\
\hline
\end{tabular}

Tabel 2 terlihat bahwa Asymp.sig.(2tailed) sebesar 0,005 jika dibandingkan dengan signifikansi $5 \%$ maka $0,005<0,05$ sehingga hipotesis alternative diterima. Hal ini berarti bahwa model konseling kelompok dengan teknik relaksasi berbasis musik klasik efektif untuk meningkat kesulitan belajar siswa.

\section{PEMBAHASAN}

Konseling kelompok dengan teknik relaksasi berbasis musik instrumental dapat digunakan dalam mengatasi kesulitan belajar siswa. Dilakukan dalam situasi konseling kelompok dalam dinamika kelompok agar siswa efektif dalam mengungkapkan permasalahan mengenai kesulitan belajar secara bersama-sama dengan anggota lain. melalui tahapan konseling 
kelompok, yaitu: (1) tahap pembukaan, (2) tahap peralihan, (3) tahap kegiatan, (4) tahap pengakhiran. Teknik relaksasi berbasis musik instrumental akan dilaksanakan dalam tahapan ke-3 (tahap kegiatan) dalam konseling kelompok. Pada tahap kegiatan dalam konseling kelompok, pemimpin kelompok akan memberikan teknik relaksasi berbasis musik instrumental untuk mengatasi kesulitan belajar siswa sebagai anggota kelompok. Anggota kelompok akan diberikan topik-topik yang dibahas pada tiap pertemuan dalam tiap sesi konseling kelompok. Topik-topik bahasan tersebut pada akhirnya mampu mengatasi indikator dalam kesulitan belajar siswa. Pada tahap kegiatan dalam konseling kelompok, pemimpin kelompok akan memberikan strategi teknik relaksasi berbasis musik instrumental untuk mengatasi kesulitan belajar siswa.

Berdasarkan hasil analisis data dengan Uji wilcoxon menunjukkan bahwa tujuan dari model konseling kelompok dengan teknik relaksasi berbasis musik instrumental untuk mengatasi kesulitan belajar siswa telah tercapai, yakni dengan adanya perubahan dari hasil evaluasi awal dan hasil evaluasi akhir pada kesulitan belajar yang dimiliki siswa kelas VIII SMP PGRI 1 Palembang.

Kaidah yang digunakan adalah menguji hipotesis alternatif (Ha) yang berbunyi konseling kelompok dengan teknik relaksasi berbasis musik instrumental untuk mengatasi kesulitan belajar siswa. Berdasarkan hasil pengujian wilcoxon diperoleh perbedaan sebesar $-2,805$ pada nilai signifikan hitung (sig.2taled) 0,005. Perbandingan nilai signifikansi hitung dengan taraf signifikansi $5 \%(0,05)$ adalah $0,005<0,05$, sehingga hipotesis nihil (Ho) ditolak sedangkan hipotesis alternatif (Ha) diterima, maka diperoleh kesimpulan bahwa model konseling kelompok dengan-teknik relaksasi berbasis musik instrumental terbukti efektif untuk mengatasi kesulitan belajar siswa.

Konseling kelompok dengan teknik relaksasi berbasis musik instrumental berangkat dari hasil analisis kebutuhan (need assesment) sehingga relevan dengan kebutuhan di lapangan yang menunjukan perlunya upaya strategis dalam memberikan layanan yang berkualitas serta perlunya intervensi terhadap siswa yang terindikasi memiliki kesulitan belajar tinggi. Terdapat 2 aspek dan 7 indikator kesulitan belajar yang dapat mengungkap individu memiliki kesulitan belajar rendah atau tinggi, yaitu: (1) yakin dengan kemampuan diri yang dimiliki, (2) optimis mendapatkan nilai terbaik dalam proses akademik (3) memiliki tujuan dan rencana yang jelas dalam kegiatan sehari-hari (4) kinerja tinggi dalam dalam mengerjakan tugas dari guru (5) semangat dalam kegiatan akademik (6) bertanggung jawab sebagai pribadi yang menginginkan hasil dari kemampuan yang optimal (7) mampu mengontrol stres dan mengendalikan rasa cemas

Pengalaman peneliti sebagai pemimpin kelompok dalam kegiatan konseling kelompok dengan memanfaatkan teknik selaksasi berbasis musik instrumental untuk mengatasi kesulitan belajar siswa, ditemukan bahwa prosedur pelaksanaan layanan peningkatan kesulitan belajar siswa dengan konseling kelompok melalui teknik relaksasi berbasis musik instrumental memberikan peluang yang sama pada masingmasing kelompok untuk terlibat dan aktif selama kegiatan berlangsung. Mulai dari tahap pembentukan sampai pada tahap pengakhiran. Kondisi tersebut memungkinkan terlaksananya pelaksanaan pada tahapan kegiatan secara produktif bagi peningkatan kesulitan belajar siswa.

Berdasarkan hasil penelitian, ditemukan bahwa terdapat perbedaan yang signifikan antara nilai rata-rata skor kesulitan belajar siswa sebelum menerima layanan konseling kelompok dan nilai rata-rata skor kesulitan belajar siswa sesudah menerima layanan konseling kelompok. Pelaksanaan layanan konseling kelompok dengan teknik relaksasi berbasis musik instrumental efektif dalam meningkatan kesulitan belajar siswa.

Penelitian ini didukung oleh hasil dari penelitian yang dilakuakan oleh Djohan (2005 :43) dengan judul " Musik selalu berhubungan dengan pikiran sehat" yang menyatakan musik merupakan suara yang sering kita dengarkan, Musik dapat menghibur jiwa, membangkitkan semangat dan menjernihkan pikiran. Musik membuat seseorang dapat mengekspresikan diri dengan bebas, dan usik dapat membuat orang lebih cerdas, mengatasi daya ingat, mengatasi kreativitas, menyehatkan tubuh, mengatasi kecerdasan emosional, dan lain-lain

Disimpulkan bahwa konseling kelompok dengan teknik relaksasi berbasis musik instrumental memiliki kontribusi yang positif terhadap pelayanan bimbingan dan konseling di sekolah. Melalui konseling kelompok teknik 
relaksasi berbasis musik intrumental, siswa mampu mengaktualisasikan diri sesuai potensi, bakat, dan minat yang dimilikinya. Konseling kelompok teknik relaksasi ini efektif untungmengatasi kesulitan belajar siswa.

\section{DAFTAR PUSTAKA}

Alwisol, 2005. Psikologi kepribadian. UMM Press

Arikunto, S. 2010. Prosedur Penelitina Suatu Pendekatan Praktik. Jakarta: PT Rineka Cipta.

Azwar, S. 2012. Penyusunan Skala Psikologi. Edisi 2. Yogyakarta: Pustaka Pelajar.

Bandura Albert, 1995. Kesulitan belajar in Changing in societies.USA. Cambrige University Press

Borg, W.R., Gall, M.D. 2003. Educational Research: An Intruduction. London: Longman, Inc.

Corey, G. 2012. Theory \& Practice of Group Counseling (Gerald Corey Eight Edition).Canada: By Nelson Education, Ltd.

Corey. 2011. Becoming a helper sixth edition. USA,Broks/Cole, Cengage Learning

Djohan. 2009. Psikologi Musik. Yogyakarta, Best Publisher

Djohan. 2006. Terapi Musik; Teori dan Aplikasi, Yogyakarta. GalangPress

Hastomi dan Sumaryati. 2012. Terapi Musik. javalitera

Mukhid. A. 2009. Self-efficacy (perspektif teori kognitif social dan implikasinyaterhadap pendidikan). Tadris, Volume 108 4, Nomor 1, 2009

Sugiharto. 2012. Meningkatkan Kesulitan belajar Pelajaran Matematika Melalui Layanan Penguasaan Konten Teknik Modeling Simbolik.

Sugiyono. 2010. Statistik Penelitian. Bandung: Alfabeta.

Sugiyono. 2013. Metode Penelitian Pendidikan (Pendekatan Kuantitatif, Kualitatif dan $R n D)$. Bandung: Alfabeta. 